\title{
Ortaokul Öğrencilerinin Fen Bilimleri Dersindeki Yapılandırmacı Öğrenme Ortamına İlişkin Görüşleri
}

\author{
Davut SARITAȘ ${ }^{1}$ ve Hasan Hüseyin KILINÇ ${ }^{2}$
}

$\ddot{O} z$

$\mathrm{Bu}$ çalışmanın amacı, ortaokul öğrencilerinin Fen Bilimleri dersindeki yapılandırmacı öğrenme ortamını değerlendirmelerine ilişkin görüşlerinin bazı değişkenler açısından belirlemektir. Orta Anadolu'da bir ilde bulunan farklı sosyo-ekonomik düzeye sahip üç ortaokuldan 5, 6, 7 ve 8 sınıf seviyesinde öğrenim gören 259 (138 erkek, 121 kız) öğrenci üzerinde yapılan çalışmada veriler Argün ve Aşkar (2010) tarafindan geliştirilen 28 maddeden oluşan "Yapılandırmacı Öğrenme Ortamlarını Değerlendirme Ölç̧eğı" aracılığı ile toplanmışır. Nicel analiz sonucunda elde edilen bulgular şu şekilde özetlenebilir; ölçeğin tüm boyutlarında ve genel puanlar açısından öğrencilerin Fen Bilimleri dersini çok üst düzeyde olmamakla birlikte yeterli düzeyde yapılandırmacı olarak gördükleri belirlenmiştir. Ayrıca değişkenlerden sınıf düzeyi açısından anlamlı bir farklılaşma görülmemiş, ancak okulun sosyo-ekonomik düzeyi değişkeni açısından yüksek düzey okul öğrencileri lehine, cinsiyet değişkeni açısından da kız öğrenciler lehine anlamlı bir farklılaşma görülmüştür. Genel anlamda elde edilen bu sonuçlar literatürdeki benzer çalışmalar ile bazı açılardan ötüşürken bazı açılardan örtüşmemektedir.

Anabtar Kelimeler: Fen Bilimleri Dersi, Ortaokul Öğrencileri, Yapılandırmacı Öğrenme Ortamı

\section{Secondary School Students' Views on Constructivist Learning Environment in Science}

\section{Course}

\section{Abstract}

This study aims to determine the views of secondary school students regarding the constructivist learning environment in the science class in terms of some variables. In the study with 259 (5,6,7 and 8-grade students; 138 boys, 121 girls) students from three secondary schools with different socio-economic levels in a province in Central Anatolia, the data collected through the "Constructivist Learning Environments Scale." The scale consists of 28 items and developed by Argün and Aşkar (2010). The findings obtained as a result of quantitative analysis can be summarized as follows; In all dimensions of the scale and terms of overall scores, it determined that the students regarded the Science course as an adequate level of constructivist, although not at a very high standard. Besides, there was no significant difference in terms of grade-level from the variables. Still, it was a significant difference in favor of the high-level socio-economic school, and girls in terms of variables In general terms, these results overlap with similar studies in the literature in some respects, but do not correspond in some respects..

\section{Key Words: Science Course, Secondary School Students, Constructivist Learning Environment}

\section{Atıf İçin / Please Cite As:}

Sarıtaş, D. ve Kılınç, H. K. (2020). Ortaokul öğrencilerinin fen bilimleri dersindeki yapılandırmacı öğrenme ortamına ilişkin görüşleri. Manas Sosyal Araștırmalar Dergisi, 9(4), 2079-2091.

Geliş Tarihi / Received Date: 12.05 .2020

Kabul Tarihi / Accepted Date: 28.08.2020

\footnotetext{
${ }^{1}$ Dr. - Nevşehir Hacı Bektaş Veli Üniversitesi Eğitim Fakültesi, davutsaritas@gmail.com ORCID: 0000-0002-5108-4801

2 Doç. Dr. - Nevşehir Hacı Bektaş Veli Üniversitesi Eğitim Fakültesi, hhkilinc@nevsehir.edu.tr ORCID: 0000-0002-0446-2507
} 


\section{Giriş}

Yapılandırmacılık kavramı epistemolojik, pedagojik ve psikolojik açıdan farklı göndermelere sahiptir (Ünder, 2010, s. 201). Eğitim literatürde yapılandırmacıllğa katkı sunanlar arasında Kant'tan Dewey'e Piaget'den Vygotsky'e, Bruner'den Gardner'a kadar birçok isimden bahsedilmektedir (Çiftçi, Sünbül ve Köksal, 2013, s. 282). Esasen kökeninde öznelci bir bilgi felsefesi (epistemoloji) yatan yapılandırmacilı̆̆ın geçen yüzyllda psikolojik zeminde bir öğrenme kuramı olarak kendini gösterdiği ve zamanla pedagojik zemini de kapladığı görülmektedir. Bu nedenle günümüz eğitim literatüründe geniş bir kullanım alanına sahiptir. Yapılandırmacılık öğrenmenin yanı sıra eğitim, öğretim ve program geliştirmeyi veya düşünsel, kişisel, bilimsel bir bilgi teorisini tanımlayan bir kuram olarak ifade edilmektedir (Matthews, 2002, s. 121). $\mathrm{Bu}$ farklı göndermeler ışığında en genel hali ile yapılandırmacılı̆̆ın bireylerin bilgiyi nasıl edindiği, nasıl anlamlandırdığı ve nasıl öğrendiğini açıklayan bir kuram veya yaklaşım olduğu söylenebilir.

Yapılandırmacı öğrenme yaklaşımın en temel savı bilginin öznel bir şekilde birey tarafindan yapılandırılmasıdır. Bu nedenle öğrenme olgusu, kişisel deneyimler üzerinden bir anlam oluşturma süreci olarak öznel bir niteliğe sahiptir (Doğanay ve Tok, 2010, s. 217). Bireysel deneyimleri anlamlandırma daha önceki bilgilerin oluşturduğu kavramsal bir filtre dolayımda gerçekleştiği için yapılandırmacı yaklaşıma göre ön bilgiler yeni öğrenmeleri belirler (Harris ve Graham, 1994, s. 238). Diğer taraftan yapılandırmacılık öğrenmeyi öğretimle aynı anda yürüyen bir süreç olarak görmez. Başka bir ifade ile bireylerin kendilerine sunulan bilgileri doğrudan kabul etmeleri bir öğrenme değildir. Öğrenme eski ve yeni öğrenmeler arasında ilişki kurularak, bu ilişkinin öznel bir şekilde yapılandırılması ile gerçekleşir (Kalpana, 2014, s. 27).

Eğitim literatüründe en sık vurgu yapılan kavramlardan birisi olan yapılandırmacllık 1980'lerden itibaren eğitimi etkilemeye başlamış, 1990’lı yıllardan itibaren de dünya genelinde eğitim programları ve uygulamaları için başat bir yaklaşım halinde gelmiştir (Ocak, 2012, s. 27; Doğanay ve Sarı, 2012, s. 23). Bu durumun ülkemiz eğitim sisteminde de karşılık bulduğu ve yapilandırmacıllı̆ı̆n özellikle 2004 sonrası fen öğretimi programlarında benimsendiği görülmektedir (Ünder, 2010, s. 201; Atila ve Sözbilir, 2016, s. 1420). Öteden beridir fen eğitimi gerek yapılandırmacıllğın gelişme sürecinde katkı sunan isimlerin modellerinden (ör. J. Piaget, J. Bruner, R. Gagné, D. Ausubel), gerekse yapılandırmacıllğın günümüzdeki yöntemlerinden (ör. 5E, 3E gibi öğrenme döngüleri) yararlana gelmiş ve bu bağlamda kavramsal öğrenmeden becerilere kadar geniş bir çerçevede olumlu sonuçlar elde etmiştir (Özmen, 2004, s. 100).

Yapılandırmacılığın öğrenmenin niteliğine yönelik kabulleri onu geleneksel davranışçı yaklaşımlardan bariz bir şekilde ayıran en önemli yönüdür. Bu kabuller eğitiminde programlamada ve bu programlar çerçevesinde öğrenmenin sağlanması için gereken unsurların niteliğinde (ör. yöntemler, öğretmenin ve öğrencinin rolüne vb. boyutlarda) belirgin değişimlere neden olmuştur (Kurtdede Fidan ve Duman, 2014, s. 145). Yapılandırmacı öğrenmenin sağlanması için gereken unsuların bir bileşimi olan öğrenme ortamının niteliklerine yönelik yapılan tanımlamalar genel olarak belli başlı özellikler etrafında şekillenmektedir. İlgili literatürün taranması ile ortaya çıkan söz konusu özellikler Doğanay ve Sarı (2012, s. 23) tarafından şu şekilde özetlenmiştir; yaşamla ilgili gerçek sorunları içerme; yüksel seviye düşünme becerilerini kullanmaya imkan verme; mevcut bilgi ve deneyimleri yenileri ile ilişkilendirmeyi sağlama; sorgulamayı, zengin görüş açılarını ortaya çıkaran ve bunların tartısıllmasına imkân veren etkinlikler sağlama; bireysel düşüncelere üretmek için firsat ve sorumluluk sağlama; bilgiler arasında bütüncül ilişkileri öne çıkarak bakış açısını oluşturma; az sayıda kavramı derinlemesine ele alma; öğrenme ortamını oluşmasında öğrencilere yetki verme; işbirliği aracilı̆̆ ile etkileşime teşvik etme; teknoloji kullanmayı özendirme ve değerlendirmeyi öğrenme sürecinin bileşeni olarak işlevsel hale getirme.

Yapılandırmacı öğrenme ortamının merkezinde bulunan öğrenci bazı becerileri zamanla edinmeli ve bunları öğrenme sürecinde kullanmalıdır. Yapılandırmacı yaklaşımda öğrencinin durumu ise özetle şu şekilde ifade edilebilir (Doğanay ve Sarı, 2012, s. 24; Kurt ve Bayar, 2020, s. 141; Ocak, 2012, s. 27); öğrenci bilgiyi ve anlamı öznel olarak oluşturan ve süreçte yeniden düzenleyen etkin taraftır; zamanla edindiği üst düzey bilişsel becerileri (ör. problem çözme, eleştirel ve yaratıcı düşünme) kullanarak, araştırır ve kararlar alır, etkinlikler katılma iş birliği yapma ve sorumluluk almada isteklidir.

Yapılandırmacı yaklaşımın temel vurgusunun öğretimden çok öğrenme olması, başka bir ifade ile öğreticiden daha çok öğrenen birey olması öğrencinin süreçte daha etkin olmasını gerektirmektedir (Kumar, 2006; s. 251; Naylor ve Keogh, 1999, s. 93). Ancak bu durum öğretmenin rolünü zayıflatmaz, çünkü bu ortamı hazırlayan kişi öğretmendir. Yapılandırmacı öğrenme ortamının söz konusu özellikleri incelendiğinde bu ortamı hazırlaması gereken öğretmenin kritik önemi kendini göstermektedir. Bu bağlamda öğretmenin görev ve sorumlulukları şu şekilde özetlenebilir; (Gilakjani, Leong ve Ismail, 2013, s. 
50; Schwartz, 1994 Akt: Kurtdede Fidan ve Duman, 2014; Kalpana, 2014, s. 28; Nakiboğlu, 1999, s. 273; Özden, 2020, s. 72); öğrenmenin sorumluluğunun öğrenenlerle paylaşmak; öğrenenlerin ön bilgilerini ortaya çıkarmak; alternatif kavramlarını üzerinde düşünmelerini sağlamak, öğrenenlerin doğal meraklarını aktifleştirmek, dünyayı ve deneyimleri anlamlandırmada yardımcı olmak, sınıfta yöntem çeşitliliği sağlamak, öğrenmenin sosyal doğasını ortaya çıkaracak etkinlikler yapmak, bilgi kaynaklarına ulaşmada rehberlik etmek, fiziksel imkânları ve materyal ve teknolojileri sağlamak, planlı ama esnek bir süreç oluşturmak, öğrenenleri kişisel düşüncelerini ifade etme ve sorgulamaları için yönlendirmek ve teşvik etmek.

Dünya genelinde olduğu gibi ülkemizde yapılandırmacılık ile ilgili literatür oldukça zengindir. Özellikle 2005-2006 yilından itibaren yapılandırmacılığın resmi zeminlerde benimsenmiş olması ile başlayan süreçte özellikle bu yaklaşımı doğrulayan ve geleneksel yaklaşımla karşılaştıran birçok çalışma yapılmışır (Baş, 2012, s. 205). Gelinen noktada yapılandırmacı vurgunun önceki programlara kıyasla güncel programlarda daha örtük ve belirsiz olduğu söylenebilir. Bu yapılandırmacıllğın programlarda bir varsayım olarak alındığı anlamına gelebilir. Nitekim önemli olan öğrenme ortamlarımızın ne derece yapılandırıcı kaldığıdır. Başka bir ifade ile hem öğrenme ortamlarımızdaki uygulamalara hem de öğretmen ve öğrenci anlayışlarına yapılandırmacılı̆̆ın dinamik bir şekilde yansımasının devamlılığı önemlidir. Bu noktada literatürde fen öğretmen adayları ve öğretmenlerinin yapılandırmacı yaklaşım açısından durumlarına yönelik çalışmalara rastlanmaktadır (Akpınar ve Ergin, 2005; Arsal, 2013; Atila ve Sözbilir, 2016; Birikim, 2008; Doğan, 2012; Ünal ve Akpınar, 2006; Yangın ve Karasu, 2015; Yangın ve Dindar, 2007; Yıldırım, 2011; Yılmaz, 2006). Ancak öğretmenlerin yanı sıra yapılandırmacilı̆̆ın merkeze aldığ1 öğrencilerin kendi deneyimledikleri ortamı yapılandırmacı olarak algılayıp algılamadıkları da önemlidir. Literatürde öğrencilerin görüşleri üzerinden öğrenme ortamlarının yapılandırmacı niteliğine ilişkin değerlendirmelerde bulunmaya imkân verecek çalışmalar az sayıdadır (Baş, 2012; Beyhan, 2013; Doğanay ve Sar1, 2012; Cir1k, Çolak ve Kaya, 2015; Erdoğan ve Polat, 2017). Bununla birlikte özel olarak fen bilimleri derslerindeki yapılandırmacı ortama ilişkin öğrenci görüşleri ve anlayışlarına doğrudan odaklı çalısmalar ise daha azdır (Çavuş ve Yılmaz, 2014; Zorlu ve Zorlu, 2015).

Özetle etkili bir öğretme-öğrenme sürecinin devam ettirilmesi, varsa sorunlarının tartışılması açısından ülkemizde fen bilimleri eğitiminde uzun bir süre önce benimsenen yapılandırmacı yaklaşımın öğrenme ortamlarımızdaki güncel durumu hakkında fikir verecek çalısmalara ihtiyaç vardır.

\section{Yöntem}

$\mathrm{Bu}$ araştırma betimsel nitelikte olup, öğrenci görüşlerini belirleyerek mevcut durumu olduğu gibi yansıtmak amacıyla tarama modeline göre yürütülmüsstür.

\section{Araştırmanın Amacı}

$\mathrm{Bu}$ araştırmada, ortaokul öğrencilerinin Fen Bilimleri dersindeki yapılandırmacı öğrenme ortamını değerlendirmelerine ilişkin görüşlerini belirlemek amaçlanmıştr. Bu doğrultuda belirlenen alt amaçlar şu şekildedir:

1. Öğrencilerin Fen Bilimleri dersindeki yapılandırmacı öğrenme ortamını değerlendirmelerine ilişkin görüşleri ne düzeydedir?

2. Fen Bilimleri dersindeki yapılandırmacı öğrenme ortamını değerlendirmelerine ilişkin görüşleri cinsiyet değişkenine göre farklılaşmakta mıdır?

3. Fen Bilimleri dersindeki yapılandırmacı öğrenme ortamını değerlendirmelerine ilişkin görüşleri sınıf düzeyi değişkenine göre farklılaşmakta mıdır?

4. Fen Bilimleri dersindeki yapılandırmacı öğrenme ortamını değerlendirmelerine ilişkin görüşleri okulun sosyo-ekonomik düzeyi değişkenine göre farklılaşmakta mıdır?

\section{Evren ve Örneklem}

Araştırmanın evrenini, Nevşehir il merkezinde bulunan ortaokul öğrencileri oluşturmaktadır. Örneklem belirlemede tabakalı örnekleme yöntemi kullanılmışırı. Bu örnekleme türünde, evrende bulunan alt grupların örneklemde temsil edilmelerini sağlamak amacıyla evren birden fazla tabakaya ayrilır (Balcı, 2007, s. 85). Bu nedenle, okul türü açısından gruplandırma yapılmış ve Nevşehir ilinde bulunan 1 üst, 1 orta ve 1 alt sosyo-ekonomik düzey okul seçilmiştir. Aşağıda (Tablo 1), araştırmaya katılan öğrencilere ilişkin kişisel bilgiler verilmiştir. 
Tablo 1. Öğrencilere İliskin Kişsisel Bilgiler

\begin{tabular}{|c|c|c|c|}
\hline & Değisgken & $F$ & $\%$ \\
\hline \multirow{2}{*}{ Cinsiyet } & Erkek & 138 & 53,3 \\
\hline & $\mathrm{K}_{12}$ & 121 & 46,7 \\
\hline \multirow{4}{*}{ Sınıf Düzeyi } & 5. sinif & 68 & 26,3 \\
\hline & 6. sinif & 55 & 21,2 \\
\hline & 7. sinif & 69 & 26,6 \\
\hline & 8. sinif & 67 & 25,9 \\
\hline \multirow{4}{*}{$\begin{array}{l}\text { Sosyo- } \\
\text { ekonomik } \\
\text { düzey } \\
\text { Toplam }\end{array}$} & Üst & 97 & 37,5 \\
\hline & Orta & 95 & 36,7 \\
\hline & Alt & 67 & 25,8 \\
\hline & 264 & 259 & 100 \\
\hline
\end{tabular}

Çizelge incelendiğinde; araştırmaya okul türüne göre üst sosyo-ekonomik düzey okuldan 97 (\%37,5), orta sosyo-ekonomik düzey okuldan $95(\% 36,7)$ ve alt sosyo-ekonomik düzey okuldan $67(\% 25,8)$ öğrenci katılmıştır. Bu öğrencilerden 138’i erkek (\%53,3), 121'i kız (\%46,7) öğrencidir. Araştırmaya katılan öğrencilerden 68’i (\%26,3) 5. Sinıf, 55’i (\%21,2) 6. Sinıf, 69’u (\%26,6) 7. Sinıf ve 67’si $(\% 25,9)$ 8. Sinıfta öğrenim görmektedir.

\section{Veri Toplama Aracı}

Bu çalışmada, Argün ve Aşkar (2010) tarafından açımlayıcı ve doğrulayıcı faktör analizleri yapılarak geliştirilen ve 28 maddeden oluşan "Yapılandırmacı Öğrenme Ortamlarını Değerlendirme Ölçeği" kullanılmıştır. Ölçek; ̈̈ğrenci merkę̧li, düs̈̈̈ndüren, işbirlikli, yașamla ilgili, ögretim ve değerlendirmenin bir aradalĭğ ve farkh bakış açlar olmak üzere altı alt boyuttan oluşmaktadır. Ölçeğin açıkladığ toplam varyans \%66,65 olarak tespit edilmiştir. Ölçeğin tümüne ait Cronbach Alpha iç tutarlılık katsayıs1 .96, dır. Alt boyutlarda ise şu şekilde belirlenmiştir; öğrenci merkezli .762, düşündüren .876, işbirlikli .754, yaşamla .890, öğretim ve değerlendirmenin bir aradalığı 809 ve farklı bakış açıları .827. Ölçeğe ait doğrulayıc1 faktör analizi sonucunda ise elde edilen uyum iyiliği değerleri; Ki-kare/sd değeri $(827,20 / 343=2,41)$, RMSEA= 0.076 olarak hesaplanmıştır.

\section{Verilerin Toplanması ve Analizi}

Araştırma verilerini toplamak için ilgili birimlerden gerekli izinler alınmışır. Araştırmacılar tarafından örnekleme dahil edilen öğrencilere ölçekler uygulanarak veriler toplanmıştır. Öğrencilerin ölçeği ne şekilde doldurmaları gerektiği ile ilgili gerekli bilgilendirmeler yapılmıştır. Ayrıca öğrencilerden ölçeği samimi ve doğru bir şekilde doldurmaları talep edilmiştir. Ölçekler toplandıktan sonra elde edilen veriler SPSS programına yüklenmiş ve veriler için uygun analizler yapılmıştır.

Kişisel veriler analiz edilirken yüzde ve frekans teknikleri kullanılmıştır. Cinsiyet değişkenine ilişsin karşılaştırmada öncelikli olarak normallik testi ve varyansların homojenliği bakılmış, dağılımın normal olduğu görüldüğünden bağımsız gruplar t-testi kullanılmıştır. Sınıf düzeyi ve okulun sosyo-ekonomik düzeyine ilişkin yapılan karşılaştırmalarda da aynı şekilde normallik testi yapılmış dağılımın normal olduğu görüldügünden tek yönlü varyans analizi ve anlamlı farklılıkların olduğu durumlarda Scheffe testine bakılmıştır. Ölçekte yer alan maddelere katıllım düzeyini belirlemek için "Her zaman" (5), "Çoğu zaman"(4), “Ara sıra" (3), "Nadiren" (2), "Hiçbir zaman" (1)" dereceleri tercih edilmiştir. Aritmetik ortalamalar yorumlanırken; Her zaman: 4.21-5.00; Çoğu zaman: 3.41-4.20; Ara sıra: 2.61-3.40; Nadiren: 1.81-2.60; Hiçbir zaman: 1.00-1.80. olarak belirlenmiştir. Anlamll1k düzeyi ise .05 olarak kabul edilmiştir.

\section{Bulgular ve Yorum}

Bu bölüm öğrencilerin Fen Bilimleri dersindeki yapılandırmacı öğrenme ortamını değerlendirmelerine ilişkin görüşlerinin ne düzeyde olduğu ve cinsiyet, sınıf düzeyi ve okulun sosyo-ekonomik düzeyi değişkenleri açısından ulaşılan bulgular ve yorumları içermektedir. Aşağıdaki tabloda (Tablo 2) öğrencilerin Fen Bilimleri dersindeki yapılandırmacı öğrenme ortamına ilişkin görüşlerine ait aritmetik ortalama ve standart sapma değerleri yer almaktadır. 
Tablo 2. Öğrencilerin Fen Bilimleri Dersindeki Yapılandırmacı Öğrenme Ortamm Değerlendirmelerine İliskin Aritmetik Ortalama ve Standart Sapma Değerleri

\begin{tabular}{lcc}
\hline Alt Boyutlar & $\overline{\boldsymbol{x}}$ & $\boldsymbol{s s}$ \\
\hline Öğrenci merkezli & 3,78 & 0,73 \\
Düşündüren & 3,91 & 0,66 \\
İşbirlikli & 3,54 & 0,86 \\
Yaşamla ilgili & 3,90 & 0,83 \\
Öğretim ve değerlendirmenin bir aradalı̆̆1 & 3,45 & 0,72 \\
Farklı bakış açlları & 3,94 & 0,72 \\
Toplam & 3,80 & 0,56 \\
\hline
\end{tabular}

Tablo 2 incelendiğinde öğrencilerin en yüksek düzeyde görüşü farklı bakış açıları $(\bar{x}=3,94)$, düşündüren $(\bar{x}=3,91)$ ve yaşamla ilgili $(\bar{x}=3,90)$ alt boyutlarına belirttikleri görülmektedir. Bu alt boyutları sırasıyla; öğrenci merkezli $(\bar{x}=3,78)$, işbirlikli $(\bar{x} 3,54)$ ve öğretim ve değerlendirmenin bir aradalığ $(\bar{x}=3,45)$ izlemektedir. Bu alt boyutlara ilişkin öğrencilerin “çoğu zaman” düzeyinde görüş belirttikleri tespit edilmiştir. Bu bağlamda öğrencilerin Fen Bilimleri dersini çok yüksek olmamakla birlikte yeterli derecede yapılandırmacı bir ortam olarak değerlendirdikleri ifade edilebilir.

Aşağıda (Tablo 3) öğrencilerin Fen Bilimleri dersini öğrenci merkezli öğrenme ortamı olarak değerlendirmelerine ilişkin aritmetik ortalama ve standart sapma değerleri verilmiştir.

Tablo 3. Öğrenci Merkęli Öğrenme Ortamına İlişkin Aritmetik Ortalama ve Standart Sapma Değerleri

\begin{tabular}{llcl}
\hline M.No & Bellek Stratejileri & $\overline{\boldsymbol{X}}$ & ss \\
\hline 1 & Derste fikirlerimin değerli olduğunu hissediyorum. & 3,95 & 1,06 \\
2 & Derste katılımcı olmam için firsat veriliyor. & 4,11 & 1,32 \\
3 & Kendi öğrenmemle ilgili kararları ben veriyorum. & 3,33 & 1,41 \\
4 & Dersle ilgili konularda seçim yapma şansı veriliyor. & 3,71 & 1,37 \\
Toplam & & 3,78 & 0,73 \\
\hline
\end{tabular}

Öğrencilerin Fen Bilimleri dersini ögrenci merkę̧li ögrenme ortamı olarak değerlendirmelerine ilișkin görüşleri incelendiğinde öğrencilerin en yüksek düzeyde görüşleri sırasıyla "Derste katılımcı olmam için firsat veriliyor" ( $\bar{x}=4,11)$, "Derste fikirlerimin değerli olduğunu hissediyorum" $(\bar{x}=3,95)$ ve "Dersle ilgili konularda seçim yapma şansı veriliyor" $(\overline{\mathrm{x}}=3,71)$ maddelerine belirtmişlerdir. Bu maddelere öğrenciler "çoğu zaman" düzeyinde katılmışlardır. En düşük katıldıkları madde ise "Kendi öğrenmemle ilgili kararları ben veriyorum" ( $\bar{x}=3,33)$ maddesidir. Bu maddeye ilişkin öğrencilerin "ara sıra" düzeyinde görüş belirttikleri tespit edilmiştir. Bu alt boyuta ilişkin toplam aritmetik ortalamaya bakıldığında öğrencilerin "çoğu zaman" $(\bar{x}=3,71)$ düzeyinde görüş belirtikleri görülmüsstür. Buna göre, öğrencilerin Fen Bilimleri dersini öğrenci merkezli bir ortam olarak çok üst düzeyde olmamakla birlikte yeterli düzeyde gördükleri söylenebilir.

Aşağıda (Tablo 4) öğrencilerin Fen Bilimleri dersini düşündüren öğrenme ortamı olarak değerlendirmelerine ilişkin aritmetik ortalama ve standart sapma değerleri verilmiştir.

Tablo 4. Düşündüren Ögrrenme Ortamına İlişkin Aritmetik Ortalama ve Standart Sapma Değerleri

\begin{tabular}{llcc}
\hline M.No & Bilissel Stratejiler & $\overline{\boldsymbol{x}}$ & $\boldsymbol{s} \boldsymbol{S}$ \\
\hline 1 & Dersle ilgili sorularımın cevaplarını araştırarak buluyorum & 3,77 & 1,11 \\
2 & Öğrenmekte olduğum konu üzerine düşünüyorum & 4,11 & 1,06 \\
3 & İşlenen konuyla ilgili olarak aklıma yeni fikirler, sorular geliyor & 4,04 & 1,04 \\
4 & Fikirlerimi oluştururken derinlemesine düşünüyorum & 3,78 & 1,14 \\
5 & Ders içerisinde verdiğim yanıtları sorguluyorum & 3,94 & 1,18 \\
6 & Ders beni düşünmeye sevk ediyor & 4,05 & 1,04 \\
7 & Dersin yapısı, nasıl öğrendiğim hakkında düşünmemi sağlıyor & 3,70 & 1,20 \\
Toplam & & 3,91 & 0,66 \\
\hline
\end{tabular}

Öğrencilerin Fen Bilimleri dersini düs̈̈̈ndüren ögrenme ortamı olarak değerlendirmelerine ilişkin görüşlerine bakıldığında en yüksek düzeyde sırasıyla; "Öğrenmekte olduğum konu üzerine düşünüyorum" $(\bar{x}=4,11)$, "Ders beni düşünmeye sevk ediyor" $(\bar{x}=4,05)$, "İşlenen konuyla ilgili olarak aklıma yeni fikirler, sorular geliyor" $(\bar{x}=4,04)$, Ders içerisinde verdiğim yanıtları sorguluyorum $(\bar{x}=3,94)$, Fikirlerimi oluştururken derinlemesine düşünüyorum $(\bar{x}=3,78)$, Dersle ilgili sorularımın cevaplarını araştırarak buluyorum $(\bar{x}=3,77)$, Dersin yapısı, nasıl öğrendiğim hakkında düşünmemi sağlıyor $(\bar{x}=3,70)$ maddelerini 
belirtmişlerdir. Öğrencilerin verilen maddelerin tamamına "çoğu zaman” düzeyinde katıldıkları tespit edilmiştir. Bu alt boyuta ilişkin toplam aritmetik ortalama incelendiğinde, öğrencilerin "çoğu zaman" $(\bar{x}=3,91)$ düzeyinde görüş belirtikleri görülmüştür. Buna göre, öğrencilerin Fen Bilimleri dersini çok üst düzeyde olmamakla birlikte düşündüren bir ortam olarak gördükleri söylenebilir.

Aşağıda (Tablo 5) öğrencilerin Fen Bilimleri dersini işbirlikli öğrenme ortamı olarak değerlendirmelerine ilişkin aritmetik ortalama ve standart sapma değerleri verilmiştir.

Tablo 5. Issbirlikli Öğrenme Ortamına İliskin Aritmetik Ortalama ve Standart Sapma Değerleri

\begin{tabular}{llll}
\hline M.No & Tamamlayıci Stratejiler & $\overline{\boldsymbol{x}}$ & ss \\
\hline 1 & Derste arkadaşlarımla iş birliği içinde çalışıyoruz & 3,29 & 1,39 \\
2 & Derste düşüncelerimi paylaşmaktan çekinmiyorum & 3,62 & 1,40 \\
3 & Fikirlerimi öğretmenle paylaşıorum & 1,17 & 3,95 \\
4 & Ders kapsamında diğer öğrencilerle iletişime geçiyorum & 3,31 & 3,54 \\
Toplam & & 1,39 & 0,86 \\
\hline
\end{tabular}

Öğrencilerin Fen Bilimleri dersini işbirlikli ögrenme ortamı olarak değerlendirmelerine ilişkin görüşlerine bakıldığında en yüksek düzeyde sırasıyla; "Fikirlerimi öğretmenle paylaşıyorum" ( $\bar{x}=3,95)$, ve "Derste düşüncelerimi paylaşmaktan çekinmiyorum" ( $\bar{x}=3,62)$ maddelerini belirtmişlerdir. Bu maddelere öğrenciler "çoğu zaman” düzeyinde katılmışlardır. En düşük katıldıkları madde ise "Ders kapsamında diğer öğrencilerle iletişime geçiyorum" $(\bar{x}=3,31)$ ve "Derste arkadaşlarımla iş birliği içinde çalışıyoruz" $(\bar{x}=3,29)$ maddelerinin tercih edildiği görülmektedir. Bu maddelere ilişkin öğrencilerin "ara sıra” düzeyinde görüş belirttikleri tespit edilmiştir. Bu alt boyuta ilişkin toplam aritmetik ortalamaya bakıldığında, öğrencilerin "çoğu zaman" ( $\left.\bar{x}^{-}=3,54\right)$ düzeyinde görüş belirtikleri görülmüştür. Buna göre, öğrencilerin Fen Bilimleri dersini işbirlikli bir ortam olarak çok üst düzeyde olmamakla birlikte yeterli düzeyde gördükleri söylenebilir.

Aşağıda (Tablo 6) öğrencilerin Fen Bilimleri dersinin yaşamla ilgili bir öğrenme ortamı olarak değerlendirmelerine ilişkin aritmetik ortalama ve standart sapma değerleri verilmiştir.

Tablo 6. Yaşamla İlgili Öğrenme Ortamına İlişkin Aritmetike Ortalama ve Standart Sapma Değerleri

\begin{tabular}{llcc}
\hline M.No & Üst-Bilissel Stratejiler & $\overline{\boldsymbol{x}}$ & \multicolumn{1}{c}{ ss } \\
\hline 1 & Günlük yaşamla öğrendiklerimi bağdaştırabiliyorum. & 4,10 & 1,04 \\
2 & Öğrendiklerimi nerede uygulayabileceğimi biliyorum & 3,99 & 1,18 \\
3 & Konularla yaşam arasındaki bağı kurabiliyorum & 3,78 & 1,17 \\
4 & Derste öğrendiklerimin gerçek dünyada işime yarayacağını düşünüyorum & 3,76 & 1,16 \\
Toplam & & 3,90 & 0,83 \\
\hline
\end{tabular}

Öğrencilerin Fen Bilimleri dersini yaşamla ilgili bir ögrenme ortamı olarak değerlendirmelerine ilişkin görüşlerine bakıldığında en yüksek düzeyde sırasıyla; "Günlük yaşamla öğrendiklerimi bağdaştırabiliyorum.” ( $\overline{\mathrm{x}}=4,10)$, “Öğrendiklerimi nerede uygulayabileceğimi biliyorum” $(\bar{x}=3,99)$, "Konularla yaşam arasındaki bağ1 kurabiliyorum" ( $\bar{x}=3,78)$, Derste öğrendiklerimin gerçek dünyada işime yarayacağını düşünüyorum $(\bar{x}=3,76)$ maddelerini belirtmişlerdir. Öğrencileri verilen maddelerin tamamına "çoğu zaman" düzeyinde katılmışlardır. Bu alt boyutun toplam aritmetik ortalamasına bakıldığında, öğrencilerin "çoğu zaman” ( $\bar{x}=3,90)$ düzeyinde görüş belirtikleri tespit edilmiştir. Buna göre, öğrencilerin Fen Bilimleri dersini çok üst düzeyde olmamakla birlikte yaşamla ilgili bir öğrenme ortamı olarak gördükleri söylenebilir.

Aşağıda (Tablo 7) öğrencilerin Fen Bilimleri dersini öğretim ve değerlendirmenin bir aradalığı öğrenme ortamı olarak değerlendirmelerine ilişkin aritmetik ortalama ve standart sapma değerleri verilmiştir.

Tablo 7. Ö̆rretim ve Değerlendirmenin Bir Aradalı̆ğ Ö̆rrenme Ortamına İliskin Aritmetik Ortalama ve Standart Sapma Dĕgerleri

\begin{tabular}{llrl}
\hline M.No & Duyussal Stratejiler & $\overline{\boldsymbol{x}}$ & ss \\
\hline 1 & Dersin değerlendirme kısmını, öğretici nitelikte buluyorum & 3,36 & 1,47 \\
2 & Sinav soruları derinlemesine düşünmeden çözülemiyor. & 3,29 & 1,37 \\
3 & Ders kapsamındaki değerlendirmelerin öğrenmeme katkısı oluyor & 3,88 & 1,22 \\
4 & Sinavlar, konu hakkında yeni bilgiler edinmemi sağlıyor & 4,00 & 1,19 \\
Toplam & & 0,72 & 3,45 \\
\hline
\end{tabular}


Öğrencilerin Fen Bilimleri dersini öğretim ve değerlendirmenin bir arada olduğu ̈̈ğrenme ortamı olarak değerlendirmelerine ilişkin görüşlerine bakıldığında en yüksek düzeyde sırasıyla; "Sınavlar, konu hakkında yeni bilgiler edinmemi sağlıyor" $(\bar{x}=4,00)$, ve "Ders kapsamındaki değerlendirmelerin öğrenmeme katkıs1 oluyor" $(\bar{x}=3,88)$ maddelerini belirtmişlerdir. $\mathrm{Bu}$ maddelere öğrenciler "çoğu zaman" düzeyinde katılmışlardır. En düşük katıldıkları maddeler ise "Dersin değerlendirme kısmını, öğretici nitelikte buluyorum" ( $\bar{x}=3,36)$ ve "Sınav sorular1 derinlemesine düşünmeden çözülemiyor" ( $\bar{x}=3,29)$ maddeleridir. Bu maddelere ilişkin öğrencilerin "ara sıra" düzeyinde görüş belirttikleri tespit edilmiştir. Bu alt boyutun toplam aritmetik ortalamasına bakıldığında, öğrencilerin "çoğu zaman" $(\bar{x}=3,45)$ düzeyinde görüş belirtikleri görülmüştür. Bu sonuca göre, öğrencilerin Fen Bilimleri dersini öğretim ve değerlendirmenin bir arada olduğu bir ortam olarak çok üst düzeyde olmamakla birlikte yeterli düzeyde gördükleri söylenebilir.

Aşağıda (Tablo 8) öğrencilerin Fen Bilimleri dersinin farklı bakış açıları öğrenme ortamı olarak değerlendirmelerine ilişkin aritmetik ortalama ve standart sapma değerleri verilmiştir.

Tablo 8. Farkh Bakış Açılar İlişkin Aritmetik Ortalama ve Standart Sapma Değerleri

\begin{tabular}{|c|c|c|c|}
\hline M.No & Sosyal Stratejiler & $\bar{x}$ & ss \\
\hline 1 & $\begin{array}{l}\text { Ders sayesinde, duyduklarımı, okuduklarımı kabul etmeden önce düşünmem gerektiğini fark } \\
\text { ediyorum }\end{array}$ & 4,06 & 1,05 \\
\hline 2 & Derste karşılaştı̆ı̆m soruların, birden fazla doğru cevabı olabileceğini görüyorum & 3,61 & 1,27 \\
\hline 3 & Ders sayesinde, fikirlerin zamana göre değişebileceğini fark ediyorum & 3,98 & 1,16 \\
\hline 4 & Ders sayesinde, fikirlerin kişilere göre değișebileceğini öğreniyorum & 4,04 & 1,09 \\
\hline 5 & Bir problemin çözümü için farklı yollar üretebiliyorum & 4,02 & 1,06 \\
\hline Toplam & & 3,94 & 0,72 \\
\hline
\end{tabular}

Öğrencilerin Fen Bilimleri dersinin farkh bakıs açlarmm olușturan ögrenme ortamı olarak değerlendirmelerine ilişkin görüşlerine bakıldığında en yüksek düzeyde sırasıyla; "Ders sayesinde, duyduklarımı, okuduklarımı kabul etmeden önce düşünmem gerektiğini fark ediyorum." $(\bar{x}=4,06)$, "Ders sayesinde, fikirlerin kişilere göre değişebileceğini öğreniyorum" $(\bar{x}=4,04)$, "Bir problemin çözümü için farklı yollar üretebiliyorum" $(\bar{x}=4,02)$, Ders sayesinde, fikirlerin zamana göre değişebileceğini fark ediyorum $(\bar{x}=3,98)$ ve Derste karşılaştığım soruların, birden fazla doğru cevabı olabileceğini görüyorum $(\bar{x}=3,61)$ maddelerini belirtmişlerdir. Öğrenciler tüm maddelere "çoğu zaman" düzeyinde katılmışlardır. Bu alt boyutun toplam aritmetik ortalamasına bakıldığında, öğrencilerin "çoğu zaman" ( $\bar{x}=3,94)$ düzeyinde görüş belirtikleri görülmüştür. Bu bağlamda, ögrencilerin Fen Bilimleri dersini çok üst düzeyde olmamakla birlikte farklı bakış açılarına destekleyen bir öğrenme ortamı olarak gördükleri söylenebilir. Aşağıdaki tabloda (Tablo 9) cinsiyet değişkenine ilişkin bağımsız gruplar t- Testi sonuçları yer almaktadır.

Tablo 9. Cinsiyet Değgskeenine İlişkin t- Testi Sonuclar

\begin{tabular}{|c|c|c|c|c|c|c|c|c|c|}
\hline \multirow{2}{*}{ Alt boyut } & \multirow{2}{*}{ Cinsiyet } & \multirow{2}{*}{$n$} & \multirow{2}{*}{$\bar{x}$} & \multirow{2}{*}{ ss } & \multirow{2}{*}{$s d$} & \multicolumn{2}{|c|}{ Levene } & \multirow{2}{*}{$t$} & \multirow{2}{*}{$p$} \\
\hline & & & & & & $F$ & $p$ & & \\
\hline \multirow{2}{*}{ Öğrenci merkezli } & $\mathrm{K}_{1 \mathrm{z}}$ & 138 & 3,82 & 0,72 & 257 & 0,420 & 0,517 & 0,896 & 0,371 \\
\hline & Erkek & 121 & 3,74 & 0,74 & & & & & \\
\hline \multirow{2}{*}{ Düşündüren } & $K_{1 z}$ & 138 & 4,01 & 0,59 & 257 & 2,687 & 0,102 & 2,395 & $0,017^{*}$ \\
\hline & Erkek & 121 & 3,81 & 0,72 & & & & & \\
\hline \multirow{2}{*}{ İşbirlikli } & $\mathrm{K}_{12}$ & 138 & 3,61 & 0,89 & 257 & 1,546 & 0,215 & 1,340 & 0,181 \\
\hline & Erkek & 121 & 3,46 & 0,83 & & & & & \\
\hline \multirow{2}{*}{ Yaşamla ilgili } & $\mathrm{K}_{1 z}$ & 138 & 4,04 & 0,81 & 257 & 0,718 & 0,398 & 2,976 & $0,003^{*}$ \\
\hline & Erkek & 121 & 3,75 & 0,82 & & & & & \\
\hline \multirow{2}{*}{$\begin{array}{l}\text { Öğretim ve değerlendirmenin } \\
\text { bir aradalığı }\end{array}$} & $K_{1 z}$ & 138 & 3,48 & 0,69 & 257 & 0,526 & 0,469 & 0,586 & 0,558 \\
\hline & Erkek & 121 & 3,43 & 0,75 & & & & & \\
\hline \multirow{2}{*}{ Farklı bakış açıları } & $K_{1 z}$ & 138 & 4,04 & 0,69 & 257 & 1,625 & 0,204 & 2,523 & $0,012^{*}$ \\
\hline & Erkek & 121 & 3,82 & 0,74 & & & & & \\
\hline
\end{tabular}

Tablo 9'a göre öğrencilerin görüşleri, düşündüren, yaşamla ilgili ve farklı bakış açıları alt boyutlarında cinsiyet değiş̧keni açısından istatistiksel olarak anlamlı şekilde farklılaşmaktadır $(\mathrm{p}<0.05)$. Farklılı̆̆ın kız öğrenciler lehine olduğu tespit edilmiştir. Öğrenci merkezli, işbirlikli, öğretim ve değerlendirmenin bir aradalığı alt boyutlarında ise istatistiksel açıdan anlamlı bir farklılığın olmadığ1 görülmüştür. Tüm alt boyutlarda kız öğrencilerin erkeklere göre daha yüksek düzeyde görüş belirttikleri belirlenmiştir. Elde edilen bu bulgulara göre, kız öğrencilerin erkek öğrencilere göre Fen bilgisi dersini yapılandırmacı ortam bağlamında daha yüksek düzeyde gördükleri ifade edilebilir. 
Aşağıdaki tabloda (Tablo 10) sınıf düzeyi değişkenine ilişkin varyans analizi sonuçları yer almaktadır.

Tablo 10. Sinf Düzeyi Değiskeenine İlişkin Varyans Analiz̨i (ANOV A) Sonucları

\begin{tabular}{|c|c|c|c|c|c|c|c|}
\hline Alt boyut & Sinif & $\mathrm{n}$ & $\bar{x}$ & ss & $\mathbf{F}$ & $\mathrm{p}$ & Scheffe \\
\hline \multirow{4}{*}{ Öğrenci merkezli } & 5 & 68 & 3,76 & 0,69 & 0,815 & 0,48 & - \\
\hline & 6 & 55 & 3,81 & 0,62 & & & \\
\hline & 7 & 69 & 3,87 & 0,70 & & & \\
\hline & 8 & 67 & 3,68 & 0,88 & & & \\
\hline Levene $=2,618$ & & & & & & & \\
\hline \multirow{4}{*}{ Düşündüren } & 5 & 68 & 3,95 & 0,66 & 0,900 & 0,44 & - \\
\hline & 6 & 55 & 3,98 & 0,57 & & & \\
\hline & 7 & 69 & 3,93 & 0,67 & & & \\
\hline & 8 & 67 & 3,80 & 0,72 & & & \\
\hline Levene $=0,951$ & & & & & & & \\
\hline \multirow{4}{*}{ İşbirlikli } & 5 & 68 & 3,52 & 0,81 & 0,639 & 0,59 & - \\
\hline & 6 & 55 & 3,61 & 0,76 & & & \\
\hline & 7 & 69 & 3,43 & 0,90 & & & \\
\hline & 8 & 67 & 3,61 & 0,95 & & & \\
\hline Levene $=1,583$ & & & & & & & \\
\hline \multirow{4}{*}{ Yaşamla ilgili } & 5 & 68 & 3,99 & 0,78 & 2,280 & 0,08 & - \\
\hline & 6 & 55 & 4,04 & 0,69 & & & \\
\hline & 7 & 69 & 3,93 & 0,86 & & & \\
\hline & 8 & 67 & 3,69 & 0,91 & & & \\
\hline Levene $=2,588$ & & & & & & & \\
\hline \multirow{4}{*}{$\begin{array}{l}\text { Öğretim ve değerlendirmenin bir } \\
\text { aradalı̆g }\end{array}$} & 5 & 68 & 3,52 & 0,63 & 0,814 & 0,48 & - \\
\hline & 6 & 55 & 3,44 & 0,75 & & & \\
\hline & 7 & 69 & 3,50 & 0,66 & & & \\
\hline & 8 & 67 & 3,35 & 0,83 & & & \\
\hline Levene $=2,635$ & & & & & & & \\
\hline \multirow{4}{*}{ Farklı bakış açıları } & 5 & 68 & 3,95 & 0,78 & 2,318 & 0,07 & - \\
\hline & 6 & 55 & 4,10 & 0,62 & & & \\
\hline & 7 & 69 & 3,97 & 0,68 & & & \\
\hline & 8 & 67 & 3,76 & 0,76 & & & \\
\hline Levene $=0,889$ & & & & & & & \\
\hline
\end{tabular}

Tablo 10'da verilen bulgulara göre Fen Bilimleri dersinin yapılandırmacı öğrenme bağlamında; öğrenci merkezli, düşündüren, işbirlikli, yaşamla ilgili, öğretim ve değerlendirmenin bir aradalığ1 ve farklı bakış açıları alt boyutlarında sınıf düzeyi değişkeni açısından istatistiksel olarak anlamlı bir şekilde farklılaşmamıştır ( $\mathrm{p}>0.05)$.

Aşağıdaki tabloda (Tablo 11) okulun sosyo-ekonomik düzeyi değişkenine ilişkin varyans analizi sonuçları yer almaktadır.

Tablo 11'de verilen bulgulara göre, sosyo-ekonomik düzey değişkeni açısından öğrencilerin Fen Bilimleri dersine yönelik algıları; öğrenci merkezli, işbirlikli, yaşamla ilgili, öğretim ve değerlendirmenin bir aradalığ1 ve farklı bakış açıları alt boyutlarında istatistiksel olarak anlamlı bir şekilde farklılaşmamıştır $(\mathrm{p}>0.05)$. Ancak grupların aritmetik ortalamalarına bakıldığında bu alt boyutlarda üst sosyo-ekonomik düzey okullardaki öğrencilerin, orta ve alt sosyo-ekonomik düzey okullardaki öğrencilerden daha yüksek düzeyde görüş belirttikleri görülmektedir. Düşündüren alt boyutunda ise üst sosyo-ekonomik düzey okullar ile alt sosyo-ekonomik düzey okullara arasında, üst sosyo-ekonomik düzey okullar lehine anlamlı farklılık tespit edilmiştir ( $\mathrm{p}<0.05)$. Buna göre, sosyo-ekonomik düzeyi iyi olan okullardaki öğrencilerin orta ve alt düzey okullardaki öğrencilere göre Fen Bilimleri dersini daha yapılandırmacı bir ortam olarak gördükleri söylenebilir. 
Tablo 11. Okulun Sosyo-ekonomik Düzey Değğskenine Illiskkin Varyans Analizi (ANOV A) Sonuçar

\begin{tabular}{|c|c|c|c|c|c|c|c|}
\hline Alt boyut & $\begin{array}{c}\text { Sosyo-ekonomik } \\
\text { Düzey }\end{array}$ & $\mathbf{n}$ & $\bar{x}$ & ss & $\mathbf{F}$ & $\mathrm{p}$ & Scheffe \\
\hline \multirow{3}{*}{ Öğrenci merkezli } & Üst & 97 & 3,91 & 0,65 & 2,541 & 0,08 & -- \\
\hline & Orta & 95 & 3,71 & 0,77 & & & \\
\hline & Alt & 67 & 3,68 & 0,75 & & & \\
\hline Levene $=1,309$ & $\mathrm{p}=0,272$ & & & & & & \\
\hline \multirow{3}{*}{ Düşündüren } & Üst & 97 & 4,05 & 0,65 & 3,821 & $0,02^{*}$ & $1-3$ \\
\hline & Orta & 95 & 3,86 & 0,61 & & & \\
\hline & Alt & 67 & 3,78 & 0,71 & & & \\
\hline Levene $=1,453$ & $\mathrm{p}=0,236$ & & & & & & \\
\hline \multirow{3}{*}{ Iş̧birlikli } & Üst & 97 & 3,58 & 0,84 & 0,427 & 0,65 & -- \\
\hline & Orta & 95 & 3,48 & 0,84 & & & \\
\hline & Alt & 67 & 3,58 & 0,92 & & & \\
\hline Levene $=0,404$ & $\mathrm{p}=0,668$ & & & & & & \\
\hline \multirow{3}{*}{ Yaşamla ilgili } & Üst & 97 & 4,02 & 0,80 & 2,364 & 0,09 & \\
\hline & Orta & 95 & 3,90 & 0,79 & & & \\
\hline & Alt & 67 & 3,74 & 0,88 & & & \\
\hline Levene $=0,388$ & $\mathrm{p}=0,678$ & & & & & & \\
\hline \multirow{3}{*}{$\begin{array}{l}\text { Öğretim ve } \\
\text { değerlendirmenin bir } \\
\text { aradalığ1 }\end{array}$} & Üst & 97 & 3,57 & 0,62 & 2,728 & 0,06 & -- \\
\hline & Orta & 95 & 3,44 & 0,74 & & & \\
\hline & Alt & 67 & 3,30 & 0,81 & & & \\
\hline Levene $=2,618$ & $\mathrm{p}=0,075$ & & & & & & \\
\hline \multirow{3}{*}{ Farklı bakış açları } & Üst & 97 & 4,07 & 0,67 & 2,424 & 0,09 & -- \\
\hline & Orta & 95 & 3,87 & 0,71 & & & \\
\hline & Alt & 67 & 3,85 & 0,80 & & & \\
\hline Levene $=0,670$ & $\mathrm{p}=0,513$ & & & & & & \\
\hline
\end{tabular}

\section{Tartışma, Sonuç ve Öneriler}

Bu çalışmadan elde edilen sonuçlar şu şekilde sırlanabilir;

1. Örneklemi oluşturan ilköğretim ikinci kademe öğrencileri Fen Bilimleri dersindeki öğrenme ortamının farklı boyutlarda (öğrenci merkezli, düşündüren, işbirlikli, yaşamla ilişkili ve süreç değerlendirmeli) yeterli düzeyde yapılandırmacı olduğu görüşündedir.

2. Fen bilimleri dersinin söz konusu yeterli düzeyde yapılandırmacı olduğu görüşü sınıf seviyesine göre farklılaşmamaktadır.

3. Erkek öğrencilere kıyasla kız öğrenciler fen bilimleri dersinin daha yüksek düzeyde yapılandırmacı bir öğrenme ortamı olarak görmektedir.

4. Diğer yanda sosyo-ekonomik düzeyi iyi olan okullardaki öğrencilerin orta ve alt düzey okullardaki öğrencilere göre Fen Bilimleri dersini daha yapılandırmacı bir ortam olarak görmektedirler.

Bu çalışma sonuçları, okullarımızdaki yapılandırmacı öğrenme ortamına ilişkin öğrenci görüș ve algılarını inceleyen yapılmış az sayıdaki çalışmadan elde edilen sonuçlar ile bazı açılardan örtüşürken bazı açılardan farklılaşmaktadır. Örneğin Baş (2012, s. 203) tarafından aynı ölçme aracı ile 2011 yılında 6,7 ve 8. Sınıf öğrencileri üzerinde yürütülmüş kapsamlı bir çalışmada öğrencilerinin yapılandırmacı ortam algısının "orta düzeyde" olduğu tespit edilmiştir. Bu algının cinsiyet ve sınıf seviyesi açısından anlamlı şekilde farklılaşmasa da okulun yerleşim birimine göre farklılaştığ1 görülmüşsür. Bu çalışmaya kıyasla genel anlamda öğrencilerin yapılandırmacı öğrenme ortamı algılarının daha düşük bir düzeyde belirlenmiş olduğu söz konusu çalışma ortak değişkenler açısından karşılaştırdığında sadece cinsiyet noktasında bu çalışmadan farklılaşmıştır.

Diğer taraftan Erdoğan ve Polat (2017, s. 608) tarafindan 2526 öğrenci (5, 6, 7 ve 8. Sınıf) ile nispeten daha yakın zamanda (2011-2014) yapılan boylamsal çalışmada, öğrencilerin yapılandırmacı öğrenme ortamına ilişkin alg1 düzeylerinin yüksek olduğu görülmüştür. Bu sonuç bu çalışmada elde edilen düzeyden nispeten daha yüksektir. Farklı bir ölçek kullanılmasına rağmen ortak değişkenler açısından bakıldığında ise bu çalışma ile benzer sonuçlar da elde edildiği görülmektedir. Örneğin kız öğrencilerin yapılandırmacı öğrenme algılarının tüm alt boyutlarda erkek öğrencilerden anlamlı derecede daha yüksek olduğu görülmüştür. Diğer yandan bu çalışma sonuçları ile örtüşmeyen çalışmalar da vardır (Baş, 2012; Çavuş ve Yllmaz, 2014; Kurt ve Bayar, 2020; Zorlu ve Zorlu, 2015). Örneğin Kurt ve Bayar (2020, s. 140) tarafindan yapılmış olan güncel bir çalışma ortaokul öğrencilerinin fen bilimleri dersinde yapılandırmacı öğrenme ortamı algısının cinsiyet değişkeni açısından anlamlı bir fark olmadığını bildirmiştir. 
Kurt ve Bayar (2020, s. 140) ve benzer şekilde Baş (2012, s. 203) yaptıkları çalışmalarda öğrencilerinin yapılandırmacı öğrenme ortamı algılarının sınıf düzeyi açısından farklılaşmadığına yönelik sonuçlar ortaya çıkmıştır. Bu sonuçlar bu çalışmada elde edilen sınıf düzeyine ilişkin sonuçla örtüşmektedir. Ancak bazı çalışmalarda sınıf seviyesi açısından anlamlı farklılaşmalar da görülmüştür (Çavuş ve Yılmaz, 2014; Erdoğan ve Polat, 2017; Zorlu ve Zorlu, 2015). Örneğin Erdoğan ve Polat (2017, s. 613), 5 ve 6. sinıf seviyesindeki öğrencilerin yapılandırmacı öğrenme ortamı algısının, 7 ve 8 . sınıf öğrencilerine nazaran daha yüksek seviyede olduğu rapor etmişlerdir.

Çalışmada elde edilen bir diğer bulgu okulların sosyo-ekonomik düzeyine ilişkindir. Buna göre sosyoekonomik düzeyi yüksek olan okullardaki öğrenciler fen bilimleri dersinde kendilerine sunulan öğrenme ortamını daha yapılandırmacı bulmaktadır. Benzer sonuçlara literatürde rastlanmaktadır (Baş, 2012, s. 203). $\mathrm{Bu}$ durum okuldaki öğretimin fiziksel imkânları ile ilişkilendirilebilir. Nitekim materyal, araç, gereç vb. öğretimi kolaylaştıııcı unsurların yetersizliği yapılandırmacı ortamın oluşturulmasının önündeki en büyük engeller arasinda görülmektedir (Gömleksiz ve Bulut, 2007, s. 77).

Çalışmada kullanılan ölçek alt boyutları dikkate alındığında (düşündüren ortam, işbirlikli ortam, yaşamla ilişki öğretim, süreç değerlendirme ve öğrenci merkezli öğretim) ortaokul öğrencileri genel anlamda kendilerine sunulan fen bilimleri derslerini belli bir düzeyde yapılandırmacı görmektedirler. Gerek aynı ölçekle yapılan gerekse farklı ancak benzer alt boyutlara sahip ölçeklerle yapılan çalışmalarda bu sonuçla örtüşen bulgular ortaya çıkmıştır (Baş, 2012; Çavuş ve Yılmaz, 2014; Eroğlu, Öner ve Bektaş, 2015; Erdoğan ve Polat, 2017; Mengi ve Schreglman, 2013).

Öğrencilerin kendilerine sunulan öğrenme ortamına yönelik alg1 ve görüşlerini belirleyen en büyük faktör şüphesiz öğretmenlerdir. Öğretmenlerin kendi oluşturdukları yapılandırmacı ortam hakkındaki gerek alg1 ve anlayışları gerekse uygulama düzeyleri açısından literatüre bakıldığında ise üzerinde düşünülmesi ve tartısıılması gereken bir durum kendini göstermektedir. Fen öğretmenlerinin yapılandırmac1 ortam oluşturma becerilerine ve bilgilerine yönelik eksiklerinin olduğunu (Atila ve Sözbilir, 2016, s. 1442; Ocak, 2012, s. 37; Yangin ve Karasu, 2016, s. 85) ve bunların uzun bir süredir görüldüğü (Korkmaz, 2008, s.250; Ünal ve Akpınar, 2006, s. 40) anlaşılmaktadır. Diğer taraftan bazı çalışmalarda öğretmenlerin uygulamaları ve görüşleri arasında ortaya çıkan uyumsuzluk da rapor edilmiştir. Kurtdede Fidan ve Duman (2014, s. 143), yaptığı çalışmada kullandığı ölçekle elde ettiğgi nicel verilerin öğretmenlerinin yapılandırmacı ortam algılarını yüksek çıkarken, nitel verilerin ise uygulamalarda yeterli olmadıklarını gösterdiğini ifade etmiştir. Ayrıca Doğan (2012, s. 167), yine nicel verilere dayanarak yaptı̆̆ çalışmada fen öğretmenlerinin öğretim, sınıfta iletişim, yönetim, değerlendirme ve fiziksel imkanların kullanımı gibi boyutlarda yapılandırmacı yaklaşımı yüksek bir oranda benimsedikleri tespit etmiştir. Başka bir durum ise fen öğretmenlerinin yapılandırmacıllğın bir şekilde benimsenmiş olduğu fen bilimleri öğretim programlarına olumlu baktıkları ve benimsediklerine ilişkin bulguların literatürde yer almasıdır (Cengiz, 2019, s. 125; Saraç ve Yıldırım, 2019, s. 198).

Bu genel bağlamda bakıldığında ortaokul ögrencileri kendilerine sunulan fen bilimleri dersi ortamını yapılandırmacı bulurken, öğretmenlerin de yer yer kendi öğretim süreçlerini yapılandırmacı bulmaları uyumlu görülmektedir. Ancak fen bilimleri öğretmenlerinin pratik uygulamalarını inceleyen uzmanlar tarafından yapılandırmacı bulunamaması bir çelişki olarak önemli ve gözden kaçan bir duruma işaret edebilir. Başka bir ifade ile ortaokul öğrencilerin yapılandırmacı ortam alg1 ve görüşlerinin yüksekliği ile öğretmenlerin yapılandırmacı ortam pratiklerinin düşüklügü son derece uyumsuzdur. Bu nedenle özellikle öğrencilerin anlayışındaki yapılandırmacı öğrenme ortamı ile öğretmenlerin anlayışındaki yapılandırmacı öğrenme ortamı ve bunun uygulamalarına yansıması arasındaki farklılı̆ın nedenleri hakkında bilgi verecek çalışmalara ihtiyaç vardır. Yapılandırmacı öğrenme ortamının kalitesinin artırılmasına yönelik önerilerin verilmesi için öncelikle söz konusu durumu derinlemesine inceleyen daha nitel boyutta çalışmalar yapılabilir ve söz konusu uyumsuzluğun nedenleri ortaya çıkarılabilir.

\section{Etik Beyan}

"Ortaokul Ögrrencilerinin Fen Bilimleri Dersindeki Yapılandırmacı Öğrenme Ortamma İlişkin Görüsleri” başlıklı çalışmanın yazım sürecinde bilimsel, etik ve alıntı kurallarına uyulmuş; toplanan veriler üzerinde herhangi bir tahrifat yapılmamış ve bu çalışma herhangi başka bir akademik yayın ortamına değerlendirme için gönderilmemiştir. Çalışma Nevşehir Hacı Bektaş Veli Üniversitesi etik kurulunun 30.04.2020 tarihli 10 sayılı toplantısında 2020.10.79 numaralı gündem maddesi olarak görüşülmüşs ve çalışmanın gerçekleştirilmesinde etik sakınca bulunmadığına karar verilmiştir. 


\section{Kaynakça}

Akpınar, E. ve Ergin, Ö. (2005). Yapılandırmacı kuramda fen öğretmeninin rolleri. İlköğretim Online, 4(2),55-64.

Arsal, Z. (2013). Fen öğretimi derslerinin yapılandırmacı öğrenme ortamı açısından değerlendirilmesi. İlkögretim Online, 12 (4), 1016-1031.

Atila, M., ve Sözbilir, M . (2016). Fen ve teknoloji dersi öğretim programındaki yapılandırmacılı̆̆a dayalı öğelerin öğretmenler tarafından uygulanışı: Nitel bir çalışma. Eræincan Üniversitesi Eğitim Fakültesi Dergisi , 18(2), 1418 1457.

Balc1, A. (2007). Sosyal bilimlerde araștırma (6. Bask1). Ankara: Pegem Akademi

Baş, G. (2012). İlköğretim öğrencilerinin yapılandırmacı öğrenme ortamına ilişkin algılarının farklı değişkenler açısından değerlendirilmesi. Ĕ̈itim ve Öğretim Araștırmalar Dergisi, 1(4), 203-215.

Beyhan, Ö. (2013). The correlation of students' views on constructivist learning environment and teachers' student control ideologies. Educational Research and Reviews, 8(9), 553-559.

Birikim, Ö. (2008). Perceptions of 4 th and 5 th grade primary school students and their teachers on constructivist learning environments in science and technology courses (Doktora Tezi). Orta Doğu Teknik Üniversitesi Sosyal Bilimler Enstitüsü, Ankara.

Cengiz, E. (2019). Fen bilgisi öğretmenlerinin 2018 yllında güncellenen fen bilimleri (5, 6, 7 ve 8) dersi öğretim programlarına ilişkin düşünceleri. Academia Ë̆itim Araștırmalar Dergisi, 4(2), 125-141.

Cirık, İ., Çolak, E. ve Kaya, D. (2015). Constructivist learning environments: The teachers' and students' perspectives. International Journal on New Trends in Education and Their Implications, 6(2), 30-44

Çavuş, R. ve Yılmaz, M. M. (2014). Ortaokul öğrencilerinin fen ve teknoloji dersindeki yapılandırmacı öğrenme ortamına ilişkin görüşlerinin farklı değişkenlere göre incelenmesi. Fen Eğitimi ve Araştırmalar Derneği Fen Bilimleri Ögretimi Dergisi, 2(2), 110-128.

Çiftçi, S., Sünbül, A. M. ve Köksal, O. (2013). Sınıf öğretmenlerinin yapılandırmacı yaklaşıma göre düzenlenmiş mevcut programa ilişkin yaklaşımlarının ve uygulamalarının eğitim müfettişlerinin görüşlerine göre değerlendirilmesi. Mersin Üniversitesi Ĕgitim Fakültesi Dergisi, 9(1), 281-295.

Doğan, Y. (2012). Fen ve teknoloji dersi programında belirtilen yapılandırmacı etkinliklerin benimsenme düzeyi. Kastamonu Ë̈itim Dergisi, 20 (1), 167-186.

Doğanay, A. ve Tok, Ş. (2010). Öğretimde çağdaş yaklaşımlar. İçinde A. Doğanay (Edt.) Öğretim ilke ve yöntemleri (ss. 215-277). Ankara: PegemA.

Doğanay, A. ve Sarı, M. (2012). Yapılandırmacı öğrenme ortamı özelliklerinin düşünme dostu sınıf özelliklerini yordama düzeyi. C.Ü. Sosyal Bilimler Enstitüsü Dergisi, 21(1), 21-36.

Erdoğan, İ. ve Polat, M. (2017). Okullarımız yapılandırmacı öğrenme ortamlarına ne kadar sahip? ortaokul öğrencilerinin algıları üzerine boylamsal bir bakış. Dicle Üniversitesi Ziya Gökalp Eğitim Fakültesi Dergisi, 30, 608619. https://doi.org/10.24315/tred.552811

Gilakjani A. P., Leong L. ve Ismail, H. N. (2013). Teachers' use of technology and constructivism. I. J. Moderm Education and Computer Science, 4, 49-63.

Gömleksiz, M. N. ve Bulut, İ. (2007). Yeni fen ve teknoloji dersi öğretim programının uygulamadaki etkililiğinin değerlendirilmesi. Hacettepe Üniversitesi Ë̆itim Fakültesi Dergisi, 32(32), 76-88.

Harris, K. R. ve Graham, S. (1994). Constructivism: Principles, paradigms, and integration. The Journal of Special Education, 28(3), 233-247.

Kalpana, T. (2014). A Constructivist perspective on teaching and learning: A conceptual framework. International Research Journal of Social Sciences, 3 (1), 27-29.

Korkmaz, İ. (2008). Evaluation of teachers for restructured elementary curriculum. Education, 129(2), 250-258.

Kumar, M. (2006). Constructivist epistemology in action. The Journal of Educational Thought, 40(3), $247-261$.

Kurt, U. ve Bayar, M. F. (2020). Investigation of the perception of constructivist learning environment and classroom engagement in relationship in terms of demographic variables of middle school students. Trakya Eğitim Dergisi, 10(1), 140-150.

Kurtdede Fidan, N. ve Duman, T. (2014). Sınıf öğretmenlerinin yapılandırmacı yaklaşımın gerektirdiği niteliklere sahip olma düzeyleri. Eğitim ve Bilim, 39(174), 143-189

Matthews, M. R. (2002). Constructivism and science education: A further appraisal. Journal of Science Education and Technology 11, 121-134.

Mengi, F., ve Schreglman, S. (2013). Yapılandırmacı sınıf öğrenme ortamı algısı. Gümüşhane Üniversitesi Sosyal Bilimleri Elektronik Dergisi, 4(7), 160-174.

Nakiboğlu, C. (1999). Kimya öğretmeni eğitiminde bütünleştirici (constructivist) öğrenme modelinin öğrenci başarısına etkisi. DEÜ Buca Ë̆itim Fakültesi Dergisi Özel Sayı, 11, 271-280.

Naylor, S. ve Keogh, B. (1999). Constructivism in classroom: Theory into practice. Journal of Science Teacher Education, 10, 93-106.

Ocak, G. (2012). Öğretmenlerin yapılandırmacı öğrenme ortamı kurma başarılarının öğretmen ve öğretmen adaylarınca değerlendirilmesi. Eğitim ve Bilim, 37(166), 25-39.

Özden, Y. (2020). Ögrenme ve ögretme (13. Baskı). Ankara: Pegem Akademi

Özmen, H. (2004). Fen öğretiminde öğrenme teorileri ve teknoloji destekli yapılandırmacı (constructivist) öğrenme. The Turkish Online Journal of Educational Technology, 3(1), 100-111. 
Saraç,E., ve Yıldırım, M. S. (2019). Fen bilimleri dersi öğretim programına yönelik öğretmen görüşleri. Academy Journal of Educational Sciences, 3(2), 198-151.

Eroğlu, S., Armağan, F. Ö., ve Bektaş, O. (2015). Fen bilimleri dersi öğrenme ortamlarının yapılandırmacı özellikler açısından değerlendirilmesi. Ahi Evran Üniversitesi Kırşehir Eğitim Fakültesi Dergisi (KEFAD), 16(2), $293-312$.

Ünal, G., ve Akpinar E. (2006). To what extent science teachers are constructivist in their classrooms. Journal of Baltic Science Education, 2(10), 40-50.

Ünder, H. (2010). Yapılandırmacılığın epistemolojik savlarının Türkiye'de ilköğretim fen ve teknoloji dersi programlarında görünümleri. Eg̈itim ve Bilim, 35(158), 199-214.

Yangın, S., ve Karasu, M. (2016). Fen ve teknoloji öğretmenlerinin yapılandırmacı öğrenme uygulamaları (gözlem, görüşme ve video-kayıt incelemesi). Recep Tayyip Erdoğan Üniversitesi Sosyal Bilimler Dergisi, 2(3), 73-97. https://dergipark.org.tr/tr/pub/rteusbe/issue/26017/274013

Yangın, S., ve Dindar, H. (2007). İlköğretim fen ve teknoloji programındaki değişimin öğretmenlere yansımaları. Hacettepe Üniversitesi Eğitim Fakültesi Dergisi, 33, 240-252.

Yıldırım, F.S. (2011). İlköğretimde fen ve teknoloji ögretmenlerinin yapılandırmac ögrrenme ortamina ilişkin görüsleri (Yüksek Lisans Tezi). Selçuk Üniversitesi, Konya

Yılmaz, B. (2006). Beşinci sinf ögretmenlerinin fen ve teknoloji dersinde yapılandermacı ögrenme ortam düzenleme becerileri (Yüksek Lisans Tezi). Yıldız Teknik Üniversitesi, İstanbul.

Zorlu, Y., ve Zorlu, F. (2015). Fen ve teknoloji dersinde öğrenme ortamına yönelik öğrencilerin düzeyleri ve öğretmenlerin görüşleri. Route Educational and Social Science Journal, 2(1), 103-114.

\section{EXTENDED ABSTRACT}

Constructivism is an approach that has started to affect education since the 1980s and is a dominant approach for education programs and applications worldwide since the 1990s (Ocak, 2012, p. 27; Doğanay, \& Sar1, 2012, p. 23). This effect of constructivism reflected in science education. As a result, in Turkey since 2005, it was adopted in the official curriculum for science education (Ünder, 2010, p. 201; Atila, \& Sözbilir, 2016, p. 1420). It can say that constructivist emphasis is more implicit in current science education programs compared to the first programs and taken as an assumption in the programs. In this context, the question of how constructive our learning environments remain raised. Few studies in the literature will allow evaluating the constructivist nature of the current learning environments based on the opinions of the students (Baş, 2012; Doğanay, \& Sarı, 2012; Cırık, Çolak, \& Kaya, 2015; Erdoğan, \& Polat, 2017). Besides, there are fewer studies directly focused on the students' views and understanding of the constructivist environment in science classes (Zorlu, \& Zorlu, 2015; Çavuş, \& Yılmaz, 2014). For these reasons, there is a need for studies that will give an idea about the current status of the constructivist approach adopted in science education for a long time to continue an effective teaching-learning process and to discuss its problems, if any.

This research is a descriptive study in the screening model to determine the views of students in the city center of Nevşehir regarding the constructivist learning environment in the Science course. The universe of the research consists of secondary school students in the center of Nevşehir. Stratified sampling preferred in sample selection. One upper, one middle, and one lower socio-economic level school chosen in Nevşehir province. A total of 259 (5, 6, 7 and 8. grade) students reached. In the study, the Constructivist Learning Environments Scale consisting of 28 items developed by Argün and Aşkar (2010) used. Scale: It consists of six sub-dimensions: student-centered, thought-provoking, cooperative, life-related, teaching-assessment coexistence, and different perspectives. The data analyzed by the SPSS package program. Percentage and frequency techniques used in the analysis of personal data. In the comparisons of the data regarding the gender variable, the normality test, and the homogeneity of the variances tested, and independent groups t-test was used, by seeing that the distribution was normal. In the comparisons between the class and the socio-economic levels, the test also conducted with a normal distribution. One-way analysis of variance performed by seeing that the distribution was normal and Scheffe test applied in cases where there were significant differences.

The results obtained from the study can be summarized as follows. Firstly, second-grade students, think that the learning environment in the Science course is sufficiently constructivist in different dimensions (student-centered, thought-provoking, cooperative, life-related, teaching-assessment coexistence and different perspectives). Compared to boys, girls see the science class as a higher constructivist learning environment. The view that the science course is sufficiently constructivist does not differ according to the grade level. On the other hand, the students in schools with high socio-economic level see the environment in Science lessons as a more constructivist environment than the students in middle and lower schools. 
The results obtained generally overlap with the results of a few other studies examining student views and perceptions about the constructivist learning environment and differ in some respects. For example, the results differed only from the point of gender from a comprehensive study conducted by Baş (2012, p. 203) with the same measuring tool on 6.7 and 8th-grade students. On the other hand, the results coincide with the results of Kurt and Bayar's (2020, p.140) study with secondary school students that there is no difference at the grade level. However, some studies have also reported significant differences in this respect (Zorlu, \& Zorlu, 2015; Erdoğan, \& Polat, 2017; Çavuş, \& Yilmaz, 2014). Considering the scale sub-dimensions used in the study, secondary school students generally think the science courses offered to them at a certain level of constructivist. In studies conducted with the same scale or with different but similar sub-scales, findings consistent with this result have emerged (Eroğlu, Öner, \& Bektaş, 2015; Çavuş, \& Yllmaz, 2014; Erdoğan, \& Polat, 2017; Mengi, \& Schreglman, 2013; Baş, 2012).

In general, while secondary school students find the environment of science courses offered to them as constructivist, it is seen that teachers sometimes (e.g., Doğan, 2012, p. 167) find their teaching processes as. However, the fact that the science teachers' practical applications cannot be found constructivist by the experts examining (e.g., Atila, \& Sözbilir, 2016, p. 1442) may indicate a critical and overlooked situation as a contradiction. In other words, although secondary school students find science lessons as highly constructivist, the low level of constructivist teaching practices of science teachers is a contradiction. Therefore, it is seen that studies that will provide information about the causes of this contradiction are required. Conducting such studies can be expressed as a necessary recommendation. 